\title{
Knowledge, attitudes and adherence to treatment in individuals with hypertension and diabetes mellitus ${ }^{\#}$ Conhecimento atitudes e adesão ao tratamento em indivíduos com hipertensão e diabetes
}

\author{
Francielle Rosso Mazzuchello* \\ Lisiane Tuon** \\ Priscyla Waleska Simões** \\ Josete Mazon** \\ Valdemira Santina Dagostin ** \\ Cristiane Damiani Tomasi** \\ Neiva Hoepers** \\ Ioná Vieira Bez Birolo**
}

\begin{abstract}
Luciane Bisognin Ceretta**

Chronic Noncommunicable Diseases (NCD) constitute a major health problem in Brazil and corresponds to about $70 \%$ of the causes of death. The most common are systemic arterial hypertension and diabetes mellitus, which require the patients to be more closely controlled for its treatment and management ${ }^{2}$. This study aimed to analyze the knowledge, attitudes and adherence to the treatment of individuals with arterial hypertension and associated type 2 diabetes mellitus, accompanied by a Family Health team. This was a cross-sectional, descriptive and prospective quantitative approach. The population consisted of patients diagnosed with hypertension and type 2 diabetes mellitus, enrolled in the HIPERDIA program. Data were collected from August to November of 2014 through the Diabetes Knowledge Scale Questionnaire (DKN-A); Diabetes Attitudes Questionnaire (ATT-19) and Martín-Bayarre-Grade (MBG). 102 individuals were interviewed, the majority of whom were women, married, white, with low schooling, and with a median age of 68.5 years. Everyone was on medication and most of them did not practice any kind of physical activity. An unsatisfactory result was found in relation to the knowledge about the disease, negative attitude regarding the management of the disease, and partial adherence to the treatment. It is thus considered that individuals with hypertension and diabetes mellitus did not modify their attitudes regarding the adoption of healthy life habits for the more adequate coping of the disease.
\end{abstract}

Keywords: Diabetes Mellitus. Hypertension. Knowledge. Attitudes and Health Practice. Medication Adherence.

\section{Resumo}

As Doenças Crônicas Não Transmissíveis (DCNT) se constituem no maior problema de saúde do Brasil e correspondem a cerca de $70 \%$ das causas de morte, sendo as mais comuns delas a hipertensão arterial sistêmica e a diabetes mellitus tipo 2, que exigem dos pacientes acometidos maior controle em relação ao seu tratamento e manejo ${ }^{2}$. Assim, este estudo teve como objetivo analisar o conhecimento, as atitudes e a adesão ao tratamento de indivíduos com hipertensão arterial e diabetes mellitus tipo 2, os quais foram acompanhados por uma equipe do programa Saúde da Família. Trata-se, portanto, de um estudo transversal, descritivo e prospectivo de abordagem quantitativa. O quadro de indivíduos analisados foi constituído por pacientes com diagnóstico de hipertensão arterial e diabetes mellitus tipo 2 cadastrados no programa HIPERDIA. Os dados foram coletados no período de agosto a novembro de 2014, por meio dos questionários Diabetes Knowledge Scale Questionnaire (DKN-A), Attitudes Questionnaire (ATT-19) e MartínBayarre-Grau (MBG). Foram entrevistados 102 indivíduos, sendo a maioria composta por mulheres casadas, brancas, de baixa escolaridade, com idade mediana de 68,5 anos. Ao longo da pesquisa, verificou-se que todos faziam uso de medicamentos e a maioria não praticava nenhum tipo de atividade física. Constatou-se também resultado insatisfatório com relação ao conhecimento sobre a doença, atitude negativa relacionada ao manejo da doença e adesão parcial ao tratamento. Verificou-se, assim, que a maior parte dos indivíduos com hipertensão e diabetes mellitus envolvidos na pesquisa, apesar de cientes de seu quadro, escolheram não modificar suas atitudes ou adotar hábitos de vida mais saudáveis que lhes garantissem o enfrentamento mais adequado da doença.

Palavras-chave: Diabetes Mellitus. Hipertensão. Conhecimentos. Atitudes e Prática em Saúde. Adesão à Medicação.

DOI: 10.15343/0104-7809.20164004418432

\footnotetext{
*Universidade do Extremo Sul Catarinense. Criciúma, SC. Brasil. E-mail: francielle_rosso@hotmail.com.

** Universidade do Extremo Sul Catarinense. Prefeitura Municipal de Criciúma. Criciúma, SC. Brasil

"Article originated from the Multi-professional Residency Program post-graduate dissertation - UNESC- Universidade do Extremo Sul Catarinense- Criciúma - SC. Brasil.

The authors declare no conflicts of interest.
} 


\section{INTRODUCTION}

The mortality due to some chronic noncommunicable diseases (NCD) has been decreasing, however the number of people with NCD tend to increase, causing a burden to the public health service, regarding the treatments of NCD, as well as its complications. The more common NCDs are systemic arterial hypertension (SAH) and diabetes mellitus (DM), which require from the patients more control regarding their treatment and changes to their life styles'. According to Brazil's Ministry of Health (MH) in 2011, the main group of diseases responsible for deaths were the cardiovascular diseases, followed by cancer $(21 \%)$, chronic respiratory diseases $(12 \%)$ and DM $(3 \%)^{2}$.

According to the World Health Organization (WHO), Brazil represents 20\% to $30 \%$ prevalence of $\mathrm{SAH}$ in the adult urban population. Nowadays it is one of the main health problems. The emergence of $\mathrm{SAH}$ is becoming more precocious, it is estimated that $4 \%$ of the population that has $\mathrm{SAH}$ are children and adolescents. With the diabetics, the WHO estimated that by the year 2025, 350 million people would be diabetic ${ }^{3}$.

Of the people with DM, 67\% are hypertensive. Among the complications of DM, $28.5 \%$ of those aged 40 years or older have eye problems and $4.4 \%$ are blind. $44 \%$ are at risk of renal failure, requiring hemodialysis in the future. $60 \%$ to $70 \%$ have moderate to severe forms of nervous system diseases, carpal tunnel syndrome, erectile dysfunction or other problems affecting nervous tissue. $30 \%$ have a risk of lower limb amputation due to loss of sensation in the feet ${ }^{4}$.

These complications may relate to the lack of adherence to treatments that correspond to the agreement between the medical prescription and the patient's own conduct. However, many factors contribute to the lack of adherence, such as financial difficulties, poly drug prescription, therapeutic regimen, adverse drug effects, difficulty accessing the health system, inadequate physician-patient relationship, the asymptomatic characteristic of the disease and its chronicity ${ }^{25}$.

With high morbid-mortality, the complications of DM represent an important loss of quality of life. From a global economic point of view, the direct costs for DM care varies from $2.5 \%$ to $15 \%$ of healthcare spending, depending on the local prevalence of DM and the complexity of the available treatment ${ }^{5}$. In addition to financial costs, the disease carries other costs associated with pain, anxiety, inconvenience and lower quality of life, which affects DM patients and their families ${ }^{3.5}$.

With the objective of knowing the epidemiological profile of hypertension and diabetes mellitus in the Brazilian population, in 2003 the Ministry of Health created the Hypertensive and Diabetic Registration and Monitoring System - HIPERDIA. This system allows the generation of information for the acquisition, dispensation and distribution of medicines on a regular and systematic basis to all registered patients, in addition to guiding public managers in the adoption of intervention strategies $^{6}$.

The theme choice was based on the activities developed in the context of Basic Attention. The psychological praxis of nurses in the Family Health Units was also contemplated, contributing to the prevention and health promotion of the users of Brazil's Unique Health System (SUS) and the interfaces with the multidisciplinary teams.

Thus, a need was perceived to improve the knowledge about the users for their adaptation to all the activities developed in the context of primary care, as well as contemplating the psychological and emotional aspects involved in the diagnosis and adherence to the treatment of DM and SAH.

The health professional's understanding that the patient's attitudes toward treatment are not stable and much less crystallized, imposes the search for comprehensive, effective and resolute care ${ }^{7}$. The patient's knowledge about his illness, coping with and living with his health problems are very useful tools to implement strategies that aim to provide better adherence to the treatment of the individual. It is important to consider the patient's knowledge, since he carries with him a whole set of beliefs and schemes that allow a better interaction between the professional and the patient ${ }^{8}$.

The low level of knowledge and the negative 
attitudes toward the disease are factors that still interfere in the metabolic control and the adherence to the treatment. However, studies that show the relationship between demographic and clinical variables for knowledge acquisition and readiness for self-care are still scarce in the literature ${ }^{9}$.

Given this scenario, it is important to analyze the knowledge, attitudes and adherence to treatment of individuals with associated hypertension and DM in a Family Health Strategy of the city of Criciúma - SC.

\section{METHODS}

This is a cross-sectional, descriptive and prospective study of a quantitative approach, carried out in a Family Health Strategy in the city of Criciúma - SC. The sample consisted of all patients with a diagnosis of SAH and associated type 2 DM enrolled in the HIPERDIA program, who agreed to participate by signing the Free and Informed Consent Form (CEP No. 729670 of July 28 / 14). Individuals who did not agree to participate in the study, younger than 18 years, with a diagnosis of SAH and type 2 DM less than one year and those not found for up to two consecutive home visits, were excluded.

Data collection was performed from August to November of 2014, based on the HIPERDIA registers, as well as semi-structured interviews to identify the socio-demographic profile. The application of the Diabetes Knowledge Scale Questionnaire (DKN-A) $)^{10}$ was done, to evaluate the knowledge regarding the disease of the individuals. The Attitudes Questionnaire (ATT$19)^{10}$, to identify the psychological adjustment of these users and the Martín-Bayarre-Grade $(\mathrm{MBG})^{11}$ questionnaire to identify adherence to the treatment of individuals with associated SAH and type 2 DM.

The DKN-A knowledge test includes 15 questions, addressing knowledge about disease management. This test presents five broad categories: a) Basic physiology, including insulin action; b) Hypoglycemia; c) Food groups and their substitutions; d) Management of DM in the occurrence of some other disease; e) General principles of disease care. The measurement scale is 0-15 and each item is measured with a score, one (1) for correct answer and zero (0) for incorrect. Items 1 through 12 require a single correct answer. For items 13 to 15 some answers are correct and all should be checked to get a score of one (1). A high score indicates greater knowledge about $\mathrm{DM}^{10}$.

The ATT-19 contains 19 closed questions, which describe the emotional responses about the disease. Each statement was answered with the help of a five-point Likert scale, from "great disagreement" to "great agreement". Questions 11, 15 and 18 begin with the reverse score. Each response is measured by the five-point Likert scale (I totally disagree - score 1 to I fully agree - score 5). The total rate-score ranges from 19 to 95 points. A high score indicates positive attitude about the disease. The sum of the points is directly proportional to the attitudes towards DM, such that a minimum score of 19 points, indicates a completely negative attitude, and the value of 95 points for very positive attitudes, represented by social acceptance, low stress to illness, confidence and receptivity to treatment, personal efficacy, and good health perception ${ }^{10}$.

The MBG questionnaire has 12 items in the form of affirmations, with a Likert-type response with five answer possibilities that range from never to ever. To calculate the score obtained by each user, it was considered that the value 0 corresponds to never, 1 to almost never, 2 sometimes, 3 almost always and 4 always, with 48 being the totality of possible points to reach $^{10}$.

To facilitate the quantification and classification of the subjects, the authors designated three levels of adherence: total, partial, and non-adhered ${ }^{11}$. Total adherence, was designated to those who obtain 38 to 48 points; partial adherence, from 18 to 37 points; and non-adherent from 0 to 17 points.

After data collection, a database was prepared in the Statistical Package from the Social Sciences (SPSS) software version 22, an 
application also used for statistical analysis. The normality of the numerical variables was tested by the Kolmogorov-Smirnov test, which revealed non-Gaussian distribution for such variables, in this way the median and the interquartile range were calculated. The absolute $(\mathrm{n})$ and relative $(\%)$ frequency were also estimated for the qualitative variables.

Pearson's Chi-square test was used to quantify the association or independence between the dichotomized ages by the median, the gender and the schooling (years of study) were also dichotomized by the median, among the other categorical variables. The Mann-Whitney U-test was used to compare the ATT-19, DKN-A and MBG scores, among median-dichotomized age categories, gender, schooling (years of study) dichotomized by the median comorbidities, complications of DM and $\mathrm{SAH}$, and physical activity.

The Spearman rank correlation was used to quantify the correlation of ATT-19, DKN-A and $\mathrm{MBG}$ in relation to age, schooling, and diagnosis time. For all the aforementioned tests, $a=0.05$ and a $95 \%$ confidence interval were considered.

\section{RESULTS}

For the study, 102 patients were included according to the inclusion and exclusion criteria, among them, $70.6 \%(\mathrm{n}=72)$ were female and $29.4 \%(n=30)$ were male. The median age was $68.5(60.0-74.0)$ years, the majority of respondents $55.9 \%(\mathrm{n}=57)$ were married, white $(87.3 \% ; n=89)$, and retired $(71.6 \% ; n=$ 73). In relation to schooling, the median was 4.0 (3.0- 8.0$)$ years of study. Only $8(7.8 \%)$ subjects were smokers. The median amount of cigarettes consumed per day of individuals who smoke was 20.0 (4.0-21.5) cigarettes. Among the interviewees, only 3 (2.9\%) were alcoholic. As for physical exercise, only 21 (20.6\%) practice with a frequency of 3 (2.0-5.0) times in the week (Table 1). Diagnostic time for both diseases were similar, with a median time of 12.0 (6.020.0) years from diagnosis of $\mathrm{SAH}$ and median time of 10.0 (4.75-17.25) years from diagnosis of type $2 \mathrm{DM}$. The results also pointed to $\mathrm{SAH}$ as a precursor disease in relation to DM (Table $1)$.

In relation to comorbidities, $66.7 \%(\mathrm{n}=68)$ presented some associated pathology in addition to SAH and type 2 DM (Table 1). Of the twentythree comorbidities reported, the most frequent were arthrosis $(16.4 \% ; n=19)$, hyperthyroidism $(12.1 \% ; n=14)$, hypercholesterolemia $(9.5 \%$; $n$ $=11)$, generalized pain $(6.9 \% ; n=8)$ and arthritis $(6.0 \% ; n=7)$. The frequency of complications related to hypertension was $32.4 \%$ (33). The two most prevalent were stroke $(45.5 \%$; $n=15)$ and heart disease $(33.3 \% ; \mathrm{n}=11)$. In relation to DM, $7.8 \%(n=8)$ presented complications, the three main ones being diabetic neuropathy $(40.0 \% ; n=4)$, retinopathy $(20.0 \% ; n=2)$ and diabetic foot $(20.0 \% ; n=2)$ (Table 2$)$.

It was verified that all $(100 \% ; n=102)$ subjects used medicinal treatments for both hypertension and DM. $77.45 \%(n=79)$ used more than one drug to treat $\mathrm{SAH}$, of the nineteen types of drugs referred to the most commonly used were enalapril $(19.8 \% ; n=44)$, hydrochlorothiazide $(18.5 \% . n=41)$, losartan potassium $(12.6 \% ; n=28)$, and acetylsalicylic acid (9.0\%; $n=20)$. Regarding the drug treatment of DM, $65.69 \%(n=67)$ used more than one type of medication. Among the most reported were metformin $(56.2 \% ; \mathrm{n}=95)$, glibenclamide $(29.6 \% . \mathrm{n}=50)$ and $\mathrm{NPH}$ insulin (9.5\%; $n=16)$ (Table 3).

Among those with DM complications, the median age was lower for those with diabetic retinopathy and a higher median age for individuals with diabetic neuropathy, which were considered statistically significant $(p=0.005)$ for both complications. These characteristics are detailed in Table 4.

Statistically significant values $(p=0.001)$ were found in relation to marital status and gender, as shown in Table 5. These findings also show an association between smokers and alcoholics in relation to gender, being significantly higher $(P=0.001$ and $p=0.006$, 
respectively) in men (100\%; $\mathrm{n}=8$ and $100 \%$; $\mathrm{n}=3$, respectively). The relationship between gender and one of the complications of $\mathrm{SAH}$ (Stroke) was also significantly higher $(p=0.025)$ in females $(64.3 \% . n=9)$.

The results show an association between marital status and schooling, where lower schooling for married individuals $(73.7 \%$; $\mathrm{n}$ $=42$ ) and schooling higher than the median for widowed individuals $(40 \% ; \mathrm{n}=16)$, results considered statistically significant $(\mathrm{P}=$ 0.035). The findings also show an association between race and schooling, white individuals presented schooling less than or equal to the median $(66.3 \% ; n=59)$, while those who declared themselves to be black showed higher schooling than the median $(71.4 \% ; n=5)$, indicating statistical significance $(p=0.024)$. There was still an association between smokers and alcoholics and schooling, for both the schooling was statistically higher $(p=0.001$ and $p=0.015)$ than the median of studies $(100 \%$; $\mathrm{n}=8$ and $100 \% ; \mathrm{n}=3$, respectively). Statistical significance $(p=0.018)$ was found between schooling and types of complications for $\mathrm{SAH}$, the majority of whom presented schooling less than or equal to the median $(81.8 \%$; $n=27)$ (Table 6).

As for knowledge scores and attitudes, the median was 7.0 (6.0-9.0) and 45.0 (40.7-56.0) points, respectively. Scores lower than eight for the knowledge scale indicate an unsatisfactory result for the understanding of the disease, and Scores less than 70 for the attitudes scale indicate a negative attitude regarding the management of the disease. The treatment compliance scale also obtained a median of less than 38 points. In the MBG questionnaire, the median was 30.5 (22.0-33.2) points, indicating a low level of adherence or partial adherence of the individuals to the treatment (Table 1).

Although the results may suggest association between age and knowledge scale, there was no significant difference $(p=266 ; p=518$; $p=349$, respectively) between the scale of attitudes and adherence to the treatment. In the Mann-Whitney $U$ test for DKN-A knowledge scores, ATT-19 attitudes and adherence to MBG treatment according to the gender variable, a statistical significance was not obtained $(p$
$=0.764 ; \mathrm{p}=0.278 ; \mathrm{p}=0.548$, respectively) (Table 5). In the Mann-Whitney $U$ test for the DKN-A knowledge scores, ATT-19 attitudes and adherence to MBG treatment according to the educational variable, there was also no statistical significance observed $(p=0.895 ; p=$ $0.490 ; p=0.300$, respectively). These findings are detailed in Table 6.

There was no significant difference in knowledge scores, attitudes and treatment adherence in relation to the comorbidity variable $(p=0.251 ; p=0.718 ; p=0.881$, respectively). There was also no significance difference of the knowledge scores, attitudes and adherence to the treatment in relation to the complications of DM and $\mathrm{SAH}$. Although the results may suggest an association between physical activity practiced and the scale of knowledge, attitudes and adherence to treatment, no statistical significance was found $(p=0.559 ; p=0.551$; $p=0.851$, respectively). The results are detailed in Table 7.

In Table 8, no correlations were observed, despite positive values $(\mathrm{rs}=0.109 ; \mathrm{rs}=0.045$; rs $=0.142$ ) between age and the DKN-A knowledge scale, the ATT-19 attitudes, nor the adherence to MBG treatment, possessing no significant differences $(p=0.275 ; p=0.651 ; p$ $=0.153$, respectively). There was no correlation between the knowledge scale, attitudes, and treatment adherence for the educational variable. Although the results may suggest a negative correlation ( $r s=-0.031 ; r s=-0.071$; rs $=-0.056)$, there was no statistical significance observed $(p=0.756 ; p=0.477 ; p=0.576)$.

These findings suggest a positive correlation $(r s=0.007 ; r s=0.028 ; r s=0.012)$ between the disease time of $\mathrm{SAH}$ and the three questionnaires (DKN-A, ATT-19, MBG), but there were no significant differences $(p=0.942 ; p=0.782$; $p=0.905$, respectively). There were also no correlations for DM disease time in relation to the DKN-A and ATT-19 questionnaires, despite positive values $(r s=0.125 ; p=0.209$ and $r s=$ $0.018 ; p=0.854$, respectively). These findings also suggest a negative correlation between DM disease time and the MBG questionnaire ( $r s$ $=-0.032 ; p=0.750)$. Although the results may suggest correlations, there was no significant difference. 
Table 1 - Sociodemographic and clinical characterization of patients with SAH and DM. Criciúma/SC. 2015.

\begin{tabular}{|c|c|}
\hline Variable & $\begin{array}{l}\mathrm{n}(\%) \text { or median (IQR) } \\
\mathrm{n}=102\end{array}$ \\
\hline \multicolumn{2}{|l|}{ Gender } \\
\hline Female & $72(70.6)$ \\
\hline Male & $30(29.4)$ \\
\hline \multicolumn{2}{|l|}{ Marital Status } \\
\hline Married & $57(55.9)$ \\
\hline Widowed & $40(39.2)$ \\
\hline Single & $2(2.0)$ \\
\hline Divorced & $2(2.0)$ \\
\hline Common-law marriage & $1(1.0)$ \\
\hline \multicolumn{2}{|l|}{ Race } \\
\hline White & $89(87.3)$ \\
\hline Black & $7(6.9)$ \\
\hline Brown & $6(5.9)$ \\
\hline \multicolumn{2}{|l|}{ Profession } \\
\hline Retired & $73(71.6)$ \\
\hline Housewife & $19(18.6)$ \\
\hline Pensioner & $5(4.9)$ \\
\hline Cook & $3(2.9)$ \\
\hline Driver & $2(2.0)$ \\
\hline \multicolumn{2}{|l|}{ Smoker } \\
\hline Yes & $8(7.8)$ \\
\hline No & $94(92.2)$ \\
\hline \multicolumn{2}{|l|}{ Alcoholic } \\
\hline Yes & $3(2.9)$ \\
\hline No & $99(97.1)$ \\
\hline \multicolumn{2}{|l|}{ Physical Activity } \\
\hline Yes & $21(20.6)$ \\
\hline No & $81(79.4)$ \\
\hline \multicolumn{2}{|l|}{ Comorbidities } \\
\hline Yes & $68(66.7)$ \\
\hline No & $34(33.3)$ \\
\hline \multicolumn{2}{|c|}{ Systemic Arterial Hypertension Complications } \\
\hline Yes & $33(32.4)$ \\
\hline No & 69 (67.6) \\
\hline
\end{tabular}


...continued - Table 1

\section{Diabetes Melittus Complications}

$\begin{array}{ll}\text { Yes } & 8(7.8) \\ \text { No } & 94(92.2)\end{array}$

\section{Systemic Arterial Hypertension Treatment}

Yes $102(100.0)$

\begin{tabular}{ll} 
No & $0(0.0)$ \\
\hline Diabetes Melittus Treatments & $102(100.0)$ \\
\hline Yes & $0(0.0)$ \\
No & $68.5(60.0-74.0)$ \\
\hline Median age (in years) & $4.0(3.0-8.0)$ \\
Median schooling (in years) & $12.0(6.0-20.0)$ \\
SAH diagnostic time (in years) & $10.0(4.7-17.2)$ \\
DM diagnostic time (in years) & $20.0(4.0-21.5)$ \\
The quantity of cigarettes smoked per day & $3.0(2.0-5.0)$ \\
Practice of physical activity performed during the week & $7.0(6.0-9.0)$ \\
DKN-A general score & $45.0(40.7-56.0)$ \\
ATT-19 general score & $30.5(22.0-33.2)$ \\
MBG general score &
\end{tabular}

IQR- Interquartile Range

${ }^{*} \mathrm{SAH}$ - Systemic Arterial Hypertension

${ }^{* *}$ DM - Diabetes Mellitus

Table 2 - Distribution of comorbidities and complications among patients with SAH and DM. Criciúma/ SC. 2015.

\begin{tabular}{ll}
\hline Variable & $\begin{array}{l}\mathbf{n}(\mathbf{\%}) \\
\mathbf{n}=\mathbf{6 8}(\mathbf{6 6 . 7})\end{array}$ \\
\hline Comorbidities & \\
\hline Generalized pain & $8(6.9)$ \\
Arthrosis & $19(16.4)$ \\
Arthrits & $7(6.0)$ \\
Hypercholesterolemia & $11(9.5)$ \\
Depression & $4(3.4)$ \\
Benign Prostatic Hyperplasia & $6(5.2)$ \\
Anaemia & $5(4.3)$ \\
Back trouble & $6(5.2)$ \\
Hyperthyroidism & $14(12.1)$ \\
Others & $46(30.9)$ \\
\hline
\end{tabular}


...continued - Table 1

\section{SAH Complications}

Cardiovascular Disorders

Stroke

Cardiac Arrhythmia

Congestive Heart Failure

\section{DM Complications}

Diabetic neuropathy

Diabetic foot disease

Diabetic retinopathy

* \% Regarding to the 102 patients

** SAH - Systemic Arterial Hypertension

${ }^{* * *}$ DM - Diabetes Mellitus

Table 3 - Pharmacological treatment used for SAH and DM. Criciúma/SC. 2015.

\begin{tabular}{|c|c|}
\hline Variable & $\begin{array}{l}n(\%) \\
n=102(100.0)\end{array}$ \\
\hline \multicolumn{2}{|l|}{ SAH medication treatment } \\
\hline Verapamil & $9(4.1)$ \\
\hline Losartan potassium & $28(12.6)$ \\
\hline Amlodipine & $18(8.1)$ \\
\hline Hydrochlorothiazide & $41(18.5)$ \\
\hline Enalapril & $44(19.8)$ \\
\hline Acetylsalicylic acid & $20(9.0)$ \\
\hline Propranolol & $11(5.0)$ \\
\hline Atenolol & $16(7.2)$ \\
\hline Others & $35(16.0)$ \\
\hline DM medication treatment & $n=102(100.0)$ \\
\hline Metformin & $95(56.2)$ \\
\hline Glibenclamide & $50(29.6)$ \\
\hline $\mathrm{NPH}$ Insulin & $16(9.5)$ \\
\hline Regular Insulin & $2(1.2)$ \\
\hline Onglyza & $2(1.2)$ \\
\hline Glifage (Metformin) & $2(1.2)$ \\
\hline Acarbose & $2(1.2)$ \\
\hline
\end{tabular}

$\mathrm{n}=33(32.4)$

15 (45.5)

$11(33.3)$

$5(15.2)$

$2(6.0)$

$\mathrm{n}=\mathbf{8}(7.8)$

$4(40.0)$

$2(20.0)$

$2(20.0)$

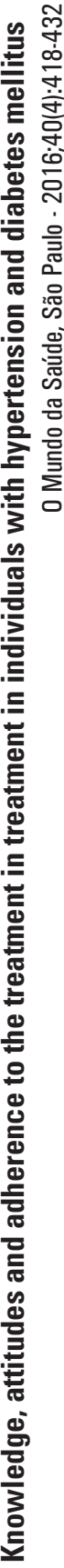


Table 4 - Characteristics of the sample stratified by age. Criciúma/SC. 2015.

\begin{tabular}{|c|c|c|c|}
\hline Variable & $\begin{array}{l}\text { Age } \\
<=\text { median } \\
n(\%) \\
n=68.5\end{array}$ & $\begin{array}{l}\text { >median } \\
\mathrm{n}(\%) \\
\mathrm{n}=69\end{array}$ & $\mathbf{P}$ \\
\hline \multicolumn{4}{|l|}{ Gender } \\
\hline Male & $13(43.3)$ & $17(56.7)$ & 0.385 \\
\hline Female & $38(52.8)$ & $34(47.2)$ & \\
\hline \multicolumn{4}{|l|}{ Marital Status } \\
\hline Single & $2(100.0)$ & $0(0.0)$ & \\
\hline Married & $32(56.1)$ & $25(43.9)$ & \\
\hline Widowed & $16(40.0)$ & $24(60.0)$ & 0.114 \\
\hline Common-law marriage & $1(100.0)$ & $0(0.0)$ & \\
\hline Divorced & $0(0.0)$ & $2(100.0)$ & \\
\hline
\end{tabular}

\begin{tabular}{llll}
\hline Race & & & \\
\hline White & $44(49.4)$ & $45(50.6)$ & \\
Brown & $3(50.0)$ & $3(50.0)$ & 0.926 \\
Black & $4(57.1)$ & $3(42.9)$ & \\
\hline Smokers (yes). 8(7.8) & $5(62.5)$ & $45(50.6)$ & 0.461 \\
Alcoholic (yes). 3(2.9) & $3(100.0)$ & $3(50.0)$ & 0.079 \\
Physical Activity (yes). 21(20.6) & $14(66.7)$ & $3(42.9)$ & 0.087 \\
Comorbidities (yes). 73(71.6) & $38(52.1)$ & $3(37.5)$ & 0.510 \\
SAH Complications (yes). 33(32.4) & $17(51.5)$ & $16(48.5)$ & 0.832 \\
\hline Stroke & $5(35.7)$ & $9(64.3)$ & 0.119 \\
Cardiac arrhythmia & $4(80.0)$ & $1(20.0)$ & 0.166 \\
Cardiovascular disorders & $7(46.7)$ & $8(53.3)$ & 0.611 \\
Congestive heart failure & $1(50.0)$ & $1(50.0)$ & 0.965 \\
\hline DM Complications. 8(7.8) & $4(50.0)$ & $4(50.0)$ & 1.000 \\
\hline Diabetic foot disease & $0(0.0)$ & $2(100.0)$ & 0.102 \\
Diabetic retinopathy & $4(100.0)$ & $0(0.0)$ & $0.005^{*}$ \\
Diabetic neuropathy & $0(0.0)$ & $4(100.0)$ & $0.005^{*}$ \\
\hline DKN-A score. median (IQR) & $8.0(6.0-9.0)$ & $7.0(5.0-9.0)$ & 0.266 \\
ATT-19 score. median (IQR) & $45.0(40.0-56.0)$ & $45.0(41.0-56.0)$ & 0.518 \\
MBG score. median (IQR) & $33.0(24.0-33.0)$ & $28.0(22.0-34.0)$ & 0.349 \\
\hline
\end{tabular}

* Statistical Significance

** IQR- Interquartile Range

${ }^{* * *} \mathrm{SAH}$ - Systemic Arterial Hypertension

$* * * *$ DM - Diabetes Mellitus 
Table 5 - Characteristics of the sample stratified by gender. Criciúma/SC. 2015.

\begin{tabular}{|c|c|c|c|}
\hline Variable & $\begin{array}{l}\text { Age } \\
<=\text { median } \\
\mathrm{n}(\%) \\
\mathrm{n}=\mathbf{6 8 . 5}\end{array}$ & $\begin{array}{l}\text { >median } \\
\mathbf{n}(\%) \\
\mathbf{n}=69\end{array}$ & $\mathbf{P}$ \\
\hline \multicolumn{4}{|l|}{ Marital Status } \\
\hline Single & $2(100.0)$ & $0(0.0)$ & \\
\hline Married & $26(45.6)$ & $31(54.4)$ & \\
\hline Widowed & $1(2.5)$ & $39(97.5)$ & $0.001^{*}$ \\
\hline Common-law marriage & $0(0.0)$ & $1(100.0)$ & \\
\hline Divorced & $1(50.0)$ & $1(50.0)$ & \\
\hline \multicolumn{4}{|l|}{ Race } \\
\hline White & $29(32.6)$ & $60(67.4)$ & \\
\hline Brown & $0(0.0)$ & $6(100.0)$ & 0.157 \\
\hline Black & $1(14.3)$ & $6(85.7)$ & \\
\hline Smokers (yes). 8(7.8) & $8(100.0)$ & $0(0.0)$ & $0.001^{*}$ \\
\hline Alcoholic (yes). 3(2.9) & $3(100.0)$ & $0(0.0)$ & $0.006^{*}$ \\
\hline Physical Activity (yes). 21(20.6) & $7(33.3)$ & $14(66.7)$ & 0.658 \\
\hline Comorbidities (yes). 73(71.6) & $20(27.4)$ & $53(72.6)$ & 0.479 \\
\hline SAH Complications (yes). 33(32.4) & $6(18.2)$ & $27(81.8)$ & 0.085 \\
\hline Cardiovascular disorders & $1(6.7)$ & 14(93.3) & 0.117 \\
\hline Stroke & $5(35.7)$ & $9(64.3)$ & $0.025^{*}$ \\
\hline Cardiac arrhythmia & $0(0.0)$ & $5(100.0)$ & 0.252 \\
\hline Congestive heart failure & $0(0.0)$ & $2(100.0)$ & 0.492 \\
\hline DM Complications (yes). 8(7.8) & $1(12.5)$ & $7(87.5)$ & 0.274 \\
\hline Diabetic neuropathy & $1(25.0)$ & $3(75.0)$ & 0.285 \\
\hline Diabetic foot disease & $0(0.0)$ & $2(100.0)$ & 0.537 \\
\hline Diabetic retinopathy & $0(0.0)$ & $4(100.0)$ & 0.285 \\
\hline ATT-19 score. median (IQR) & 56.0(41.0- 56.0) & $45.0(40.0-56.0)$ & 0.278 \\
\hline DKN-A score. median (IQR) & 7.0(6.0-9.0) & 7.5(5.2-9.0) & 0.764 \\
\hline MBG score. median(IQR) & $28.0(22.7-33.0)$ & $33.0(22.0-35.5)$ & 0.548 \\
\hline
\end{tabular}

* Statistical Significance

**IQR-Interquartile Range

${ }^{* * *}$ SAH - Systemic Arterial Hypertension

${ }^{* * *} D M$ - Diabetes Mellitus 
Table 6 - Characteristics of the sample stratified by schooling. Criciúma/SC. 2015.

\begin{tabular}{|c|c|c|c|}
\hline Variable & $\begin{array}{l}\text { Schooling } \\
<=\text { median } \\
\mathrm{n}(\%) \\
\mathrm{n}=\mathbf{4}\end{array}$ & $\begin{array}{l}\text { >median } \\
\mathrm{n}(\%) \\
\mathrm{n}=4\end{array}$ & $\mathbf{P}$ \\
\hline Age & $28(54.9)$ & $23(45.1)$ & $0.028^{*}$ \\
\hline \multicolumn{4}{|l|}{ Gender } \\
\hline Male & 19(63.3) & $11(36.7)$ & 0.741 \\
\hline Female & 48(66.7) & $24(33.3)$ & \\
\hline \multicolumn{4}{|l|}{ Marital Status } \\
\hline Single & $0(0.0)$ & $2(100.0)$ & \\
\hline Married & $42(73.7)$ & $15(26.3)$ & \\
\hline Widowed & $24(60.0)$ & $16(40.0)$ & \\
\hline Common-law marriage & $1(100.0)$ & $0(0.0)$ & $0.035^{*}$ \\
\hline Divorced & $0(0.0)$ & $2(0.0)$ & \\
\hline \multicolumn{4}{|l|}{ Race } \\
\hline White & $59(66.3)$ & $30(33.7)$ & \\
\hline Brown & $6(100.0)$ & $0(0.0)$ & $0.024^{*}$ \\
\hline Black & $2(28.6)$ & $5(71.4)$ & \\
\hline Smoker (yes). 8(7.8) & $0(0.0)$ & $8(100.0)$ & $0.001^{*}$ \\
\hline Alcoholic (yes). 3(2.9) & $0(0.0)$ & $3(100.0)$ & $0.015^{*}$ \\
\hline Physical activity (yes). 21(20.6) & $11(52.4)$ & $10(47.6)$ & 0.150 \\
\hline Comorbidities (yes). 73(71.6) & $49(67.1)$ & $24(32.9)$ & 0.628 \\
\hline SAH Complications (yes). 33(32.4) & $27(81.8)$ & $6(18.2)$ & $0.018^{*}$ \\
\hline Cardiovascular disorders & $13(86.7)$ & $2(13.3)$ & 0.510 \\
\hline Stroke & $12(85.7)$ & $2(14.3)$ & 0.618 \\
\hline Cardiac arrhythmia & $3(60.0)$ & $2(40.0)$ & 0.170 \\
\hline Congestive heart failure & $2(100.0)$ & $0(0.0)$ & 0.492 \\
\hline DM Complications (yes). 8(7.8) & $6(75.0)$ & $2(25.0)$ & 0.563 \\
\hline Diabetic neuropathy & $4(100.0)$ & $0(0.0)$ & 0.102 \\
\hline Diabetic foot disease & $2(100.0)$ & $0(0.0)$ & 0.346 \\
\hline Diabetic retinopathy & $2(50.0)$ & $2(50.0)$ & 0.102 \\
\hline DKN-A score. median (IQR) & 7.0(6.0-9.0) & 8.0(5.0-9.0) & 0.895 \\
\hline ATT-19 score. median (IQR) & $45.0(41.0-56.0)$ & $45.0(40.0-56.0)$ & 0.490 \\
\hline MBG score. median (IQR) & $33.0(22.0-36.0)$ & $28.0(22.0-33)$. & 0.300 \\
\hline
\end{tabular}

* Statistical Significance

**IQR-Interquartile Range

***SAH - Systemic Arterial Hypertension

****DM - Diabetes Mellitus 
Table 7 - Characteristics of the sample stratified by the knowledge, attitudes and treatment adherence scales. Criciúma/SC. 2015.

\begin{tabular}{|c|c|c|c|c|c|c|}
\hline Variable & DKN-A & & АТT-19 & MBG & & \\
\hline Comorbidities & & $\mathbf{P}$ & & $\mathbf{P}$ & & $P$ \\
\hline Yes & $7.0(6.0-9.5)$ & 0.251 & $45.0(40.5-56.0)$ & 0.718 & $29.0(22.0-35.0)$ & 0.881 \\
\hline No & 7.0(5.0-9.0) & & $45.0(40.5-63.0)$ & & $33.0(23.5-33.0)$ & \\
\hline \multicolumn{7}{|c|}{ SAH Complications } \\
\hline Yes & $8.0(6.0-9.0)$ & 0.746 & $45.0(40.0-56.0)$ & 0.684 & $33.0(23.0-36.5)$ & 0.262 \\
\hline No & 7.0(5.0-9.0) & & $45.0(41.0-56.0)$ & & $28.0(22.0-33.0)$ & \\
\hline \multicolumn{7}{|c|}{ DM Complications } \\
\hline Yes & $6.5(6.0-8.0)$ & 0.363 & $42.5(35.0-56.0)$ & 0.283 & $33.0(24.2-35.0)$ & 0.447 \\
\hline No & 7.0(5.7-9.0) & & $45.0(41.0-56.0)$ & & 29.0(22.0-33.0) & \\
\hline \multicolumn{7}{|l|}{ Physical Activity } \\
\hline Yes & $8.0(5.5-9.5)$ & 0.559 & $48.0(35.0-56.0)$ & 0.551 & $33.0(23.5-33.0)$ & 0.851 \\
\hline No & 7.0(6.0-9.0) & & $45.0(41.0-56.0)$ & & $29.0(22.0-34.0)$ & \\
\hline
\end{tabular}

*Statistical Significance

Table 8 - Correlation of the variables in relation to the knowledge, attitudes and treatment adherence scales. Criciúma/SC. 2015.

\begin{tabular}{|c|c|c|c|c|c|c|}
\hline \multirow{2}{*}{ Variable } & \multicolumn{2}{|c|}{ DKN-A } & \multicolumn{2}{|c|}{ АТT-19 } & \multicolumn{2}{|c|}{ MBG } \\
\hline & rs & $\mathbf{P}$ & rs & $\mathbf{P}$ & rs & $\mathbf{P}$ \\
\hline Age & 0.109 & 0.275 & 0.045 & 0.651 & 0.142 & 0.153 \\
\hline Schooling & -0.031 & 0.756 & -0.071 & 0.477 & -0.056 & 0.576 \\
\hline Disease time $\mathrm{SAH}$ & 0.007 & 0.942 & 0.028 & 0.782 & 0.012 & 0.905 \\
\hline Disease time DM & 0.125 & 0.209 & 0.018 & 0.854 & -0.032 & 0.750 \\
\hline
\end{tabular}

*Statistical Significance

\section{DISCUSSION}

The results of this study showed a higher proportion of women with $\mathrm{SAH}$ and associated type 2 DM. This discovery was also found in a study carried out in Belo Horizonte with 164 diabetics assisted by the Family Health Program of the Ventosa Health Center. The study aimed to verify socio-demographic factors, health, perception of disease and its relation to non- 
pharmacological treatment ${ }^{12}$.

The median age of the study population was 68.5 (60.0-74.0) years, the majority married. Similarities were observed in two studies where female, elderly and married individuals also predominated ${ }^{7}$. The participant's profile regarding gender and age group maintained similar characteristics to those described in another Brazilian study of $\mathrm{DM}^{13}$.

In relation to schooling, the individuals had a low level of education, with a median of 4.0 (3.0-8.0) years of study. This finding also corroborates with a study carried out with 284 people with type 2 DM who analyzed the clinical, psychological and social factors that interfere in the knowledge of individuals with DM. This study revealed that age, years of schooling, time of treatment, cognitive function, gender and level of depression were determinant variables that interfered with the individual's knowledge ${ }^{15}$. On the other hand, another study that reviews the factors related to adherence among patients with DM, showed that DM can affect people of all socioeconomic levels regardless of schooling ${ }^{16}$.

It is understood that schooling is an essential variable in the choice of innovative strategies for the empowerment of elderly patients with lower school levels. However, less schooling possibly favors non-adherence to the therapeutic plan due to the difficulty of reading and understanding prescriptions, as well as limiting access to information, and a lack of understanding the complex mechanisms of the disease and treatment. In addition, health professionals should pay attention not only to the established therapy, but also to the beliefs that support the attitudes and behaviors of the individuals ${ }^{7.12}$.

Our study revealed that a few patients associate physical exercise with the treatment of SAH and DM, that is, only 21 (20.6\%) patients do some type of physical exercise. Studies conducted in the states of São Paulo and Paraná, with type 2 DM patients, showed similar results in relation to the low level of adherence to physical activity 17 . These findings also corroborate with a study that verified the association between knowledge, attitudes, and the level of health-related physical activity practiced. This study showed that individuals who practiced some type of physical activity had a greater knowledge and more positive attitudes towards the disease ${ }^{18}$.

In a study conducted with hypertensive and diabetic patients of Francisco Morato (São Paulo), only $33.3 \%$ and $42.2 \%$ of individuals with adequate and partially adequate diet, respectively, were identified, and only $25.0 \%$ performed regular physical activity. However, despite the low number of individuals with DM and $\mathrm{SAH}$ who are adept at regular physical activities, there is evidence of the value of regular physical exercise for the prevention and rehabilitation of various chronic diseases ${ }^{19}$.

Regarding the time of disease, the individuals had a median of $12.0(6.0$ - 20.0) years for SAH and 10.0 (4.7 - 17.2) years for DM. There were similarities in a quantitative descriptive-transversal study conducted in Ribeirão Preto (São Paulo) in 2010 in a sample of 123 individuals, with the objective to relate the knowledge and attitude of users with type 2 DM with their schooling and time of illness. This study revealed a median of 11.18 years for disease time with an inverse relationship with adherence to treatment ${ }^{7}$.

Studies in São Paulo performed with people that have type $2 \mathrm{DM}$ indicate that at the time of diagnosis of DM and SAH, people already have some type of complication7. The chronic nature of the diseases, the severity of their complications and the means necessary for their control have raised costs for individuals, families, the community, and society. The progression of the disease may even limit individuals in their professional performance ${ }^{20}$.

The findings of our study revealed a knowledge score lower than 7.0 points in the application of the DKN-A questionnaire. This indicates that the subjects do not satisfactorily understand their disease. It is recognized that knowledge about the disease is essential for making decisions and changes in habits and behaviors that imply adherence to treatment. Similar results were identified in a study carried out in Ribeirão Preto, São Paulo, where the knowledge scores and attitudes regarding the disease were analyzed. In this study, most patients did not obtain satisfactory results ${ }^{14}$.

It is possible that people with DM have received some kind of information related to 
the disease throughout their lives, however, intervening factors may have limited their assimilation. A study conducted in patients with long-term type 2 DM which aimed to describe factors that influence their knowledge, identified that poor knowledge about the disease was highly influenced by their age ${ }^{21}$.

It is known that the available scientific knowledge about DM is a relevant resource for directing the health team to make clinical decisions regarding the treatment of the disease, as well as educating people with DM for their knowledge and adherence to self-care. However, it is necessary to differentiate acquisition of knowledge and level of information. Knowledge is more than reproducing information - it presupposes the modification of attitudes, behaviors, and habits of life ${ }^{7}$.

Regarding the application of the ATT-19 attitudes questionnaire, the majority of the individuals presented scores lower than 70 points, which indicates that they have not yet reached positive attitudes towards the lifestyle modifications in order to obtain proper metabolic control. Regarding the application of the MBG treatment adherence questionnaire, the majority of users had a score lower than 37 points, indicating partial treatment adherence.

It is also necessary to consider that knowledge does not always lead to a change in attitude of the user in the face of the daily demands that the treatment imposes. A study carried out in São Paulo with 79 participants compared the attitudes of patients with type 2 DM with those of health professionals regarding the management of the disease. They showed that the attitude and opinion of the

\section{CONCLUSION}

The predominant population was composed of sedentary (i.e. low amounts of physical exercise), non-smoking, less educated, retired, elderly, white, married women. The results indicating their knowledge and understanding of the disease were unsatisfactory $(<8)$. Regarding the attitude scores, the participants presented scores lower than 70 points, indicating little users are determining criteria for self-care and control. However, the attitude towards DM is also closely related to the behavior adopted by the health care professional. The greatest discrepancy is related to the need for training of health professionals and patients in relation to $\mathrm{DM}^{22}$.

Due to the amount of lifestyle changes that are needed for people with DM, adherence to treatment has been a major challenge for health care providers and practitioners in this area. Adherence to treatment implies an active attitude with spontaneous and collaborative involvement of the health professional and patient in a process of reciprocity, which leads to behavior change ${ }^{23}$.

It is necessary for the patients to be involved in the care process and be co-responsible for the adoption of their attitudes.

The Brazilian Diabetes Society Guidelines present studies demonstrating evidence that changes in lifestyle, especially with changes in diet and the increase of physical activity, have a great positive impact on the control of DM, as well as in other chronic diseases ${ }^{24}$.

The implementation of Health Education for diabetic and hypertensive patients is a great challenge for the multi-professional team. Both in relation to their training and the understanding that the acquisition of knowledge does not necessarily translate into behavioral change ${ }^{23}$. Education for self-care has a recognized importance in the treatment of people with DM and $\mathrm{SAH}$.

To accomplish this education there is a need for knowledge and training in the areas of communication, listening, and negotiation skills by the multi-professional team ${ }^{24}$.

readiness for the management of the disease. Regarding treatment adherence, the scores were below 37 points, which indicates a partial adherence to the treatment of patients with DM and $\mathrm{SAH}$. We conclude that individuals with SAH and DM did not modify their attitudes over the course of this study towards more adequate coping of the disease. 


\section{REFERÊNCIAS}

1. Duncan BB. Chor D. Aquino EML. Bensenor IM. Mill JG. Schmidt MI. Lotufo PA. Vigo A. Barreto SM. Doenças Crônicas Não Transmissíveis no Brasil: prioridade para enfrentamento e investigação. Rev. Saúde Pública. 2012; 46(1):126-134.

2. Brasil. Ministério da Saúde. Estratégias para o cuidado da pessoa com doença crônica: hipertensão arterial sistêmica. Brasília: Ministério da Saúde; 2013.

3. Brasil. Ministério da Saúde. Hipertensão arterial sistêmica para o Sistema Único de Saúde. Brasília: Ministério da Saúde; 2006.

4. Barreto TCPP. Conhecimento e Atitudes. colaborando para o desenvolvimento individual e social da população com Diabetes Mellitus. uma comunidade de Recife. Pernambuco-Brasil. [dissertation]. Recife. PE: Faculdade de Ciências da Administração de Pernambuco da UPE; 2012.

5. Barceló A. Aedo C. Rajpathak S. Robles S. The cost of diabetes in Latin American and the Caribbean. Bull. World Health Organ 2003; 81(1):2300-2304.

6. Brasil. Ministério da Saúde. Hiperdia: Sistema de Cadastramento e Acompanhamento de Hipertensos e Diabéticos. [online] Brasília. 2016.[cited 2016 Nov 14]. Available from: http://datasus.saude.gov.br/sistemas-e-aplicativos/epidemiologicos/hiperdia

7. Rodrigues FFL. Santos MA. Teixeira CRS. Gonela JT. Zanetti ML. Relação entre conhecimento. atitude. escolaridade e tempo de doença em indivíduos com diabetes mellitus. Acta paul. Enferm. 2012; 25(2):284-290.

8. Renovato RDD. Oliveira A. Percepção do paciente hipertenso sobre o processo saúde-doença e a terapêutica medicamentosa. Infarma. 2005; 17(3):72-75.

9. Torres HC. Pace AE. Stradioto MA. Análise sociodemográfica e clínica de indivíduos com diabetes tipo 2 e sua relação com o autocuidado. Cogitare Enferm. 2010; 15(1):48-54.

10. Torres HC. Hortale VA. Schall VT. Validação dos questionários de conhecimento (DKN-A) e atitude (ATT-19) de Diabetes Mellitus. Rev Saúde Pública. 2005; 39(6):906-11.

11. Martín Alfonso L. Bayarre Vea HD. Grau Ábalo JÁ. Validación Del cuestionario MBG (Martín-Bayerre-Grau) para evaluar la adherencia terapêutica em hipertensión arterial. Rev. Cubana Salud Publica. 2008; 34(1).

12. Assunção TS. Ursine PGS. Estudo de fatores associados à adesão ao tratamento não farmacológico em portadores de diabetes mellitus assistidos pelo Programa Saúde da Família. Ventosa. Belo Horizonte. Ciênc. Saúde Coletiva. 2008; 13(2):2189-2197.

13. Correr CJ. Pontarolo R. Melchiors AC. Rossignoli P. Fernández-Llimós F. Radominski RB. Tradução para o português e validação do instrumento diabetes quality of life measure. Arq Bras Endocrinol Metab. 2008; 52(3):515-22.

14. Oliveira KCS. Zanetti ML. Conhecimento e atitude de usuários com Diabetes Mellitus em um serviço de atenção básica a saúde. Rev Esc Enferm. USP 2011; 45(4):862-8.

15. Murata GH. Shah JH. Adam KD. Wendel CS. Bokhari SU. Solvas PA. et al. Factors affecting diabetes knowledge in Type 2 diabetic veterans. Diabetologia. 2003; 46(8):1170-8.

16. Delamater AM. Improving patient adherence. Clin Diabetes. 2006; 24(2):71-7.

17. Paiva DCP. Bersusa AAS. Escuder MML. Avaliação da assistência ao paciente com diabetes e/ou hipertensão pelo Programa Saúde da Família do Município de Francisco Morato. São Paulo. Brasil. Cad Saude Publica. 2006; 22(2):377-385.

18. Santos RV. Araújo VC. Associação entre conhecimento. atitudes e o nível de prática de atividade física relacionada à saúde em universitárias. [online] Revista Digital. Buenos Aires. 2011; 162(16). [cited 2016 Nov 14]. Available from: http://www.efdeportes.com/ efd162/associacao-entre-conhecimento-e-atividade-fisica.htm.

19. Barbanti EJ. Efeito da atividade física na qualidade de vida em pacientes com

depressão e dependência química. Centro de Práticas Esportivas da Universidade de São Paulo. Revista Brasileira de Atividade Física \& Saúde. 2009; 11(1):37-45.

20. Lerman I. López-Ponce A. Villa AR. Escobedo M. Caballero EA. Velasco ML. Estudio piloto de los diferentes estrategias para reforzarconductas de autocuidado y adherencia al tratamientoen pacientes de bajos recursos económicos com diabetes tipo 2. GacMédMéx. 2009; 145(1):15-9.

21. Pace AE. Ochoa-Vigo K. Caliri MHL. Fernandes APM. O conhecimento sobre diabetes melittus no processo de autocuidado. Rev. Latino-Am. Enfermagem. 2006; 14(5):84-90.

22. Oliveira KCS. Zanetti ML. Conhecimento e atitude de usuários com diabetes mellitus em um serviço de atenção básica à saúde. Rev. esc. enferm. USP. 2011; 45(4):862-868.

23. Santo BEM. Souza LME. Souza ACG. Ferreira FM. Silva CNMR. Taitson PF. Adesão dos portadores de diabetes Mellitus ao tratamento farmacológico e não farmacológico na Atenção primária a saúde. Enfermagem Revista. 2012; 15(1):88-101.

24. Diretrizes da Sociedade Brasileira de Diabetes (2015-2016). Organização José Egidio Paulo de Oliveira. Sérgio Vencio. São Paulo: A.C. Farmacêutica. 2016.

Recebido em novembro de 2015. Aprovado em outubro de 2016. 